\title{
STRONGYLOIDES RATTI: IMPLICATION OF MAST CELL-MEDIATED EXPULSION THROUGH FCERI-INDEPENDENT MECHANISMS
}

\author{
WATANABE K.***, KISHIHARA K.****, HAMANO S.*, KOGA M.*, NOMOTO K.* \& TADA I.*
}

\section{Summary:}

In order to examine whether FceRl-dependent degranulation of intestinal mast cells is required for expulsion of intestinal nematode Strongyloides ratti, CD45 exon6-deficient (CD45-/-I mice were inoculated with S. ratti. In CD45-/- mice, egg excretion in feces persisted for more than 30 days following $S$. ratti larvae inoculation, whereas in wild-type (CD45+/+) mice, the eggs completely disappeared by day 20 postinfection. The number of intestinal mucosal mast cells, which are known effector cells for the expulsion of S. ratti, was 75 \% lower in CD45-/- mice compared with that in CD45+/+ mice. Adoptive transfer of wild-type T cells from CD45+/+ mice into CD45-/- mice reduced the duration of S. ratti infection to comparable levels observed in CD45+/+ mice, with concomitant increases in intestinal mucosal mast cells. These results showed that CD45 is not involved in the effector function of intestinal mucosal mast cells against $S$. ratti infection. Since FcERl-dependent degranulation of mast cells is completely impaired in these CD45 knockout mice, we conclude that FceRldependent degranulation is not required in the protective function of intestinal mucosal mast cells against primary infection of S. ratti.

KEY WORDS : Strongyloides ratti, expulsion, mast cell, degranulation, FcERl.

\section{INTRODUCTION}

Trites

ntestinal parasites that reside in the gut face several host immune factors, including mast cells (Nawa et al., 1994). Parasites deploy several strategies to escape these host immune factors; for example, parasites induce host regulatory $\mathrm{T}$ cells to dampen the immune mechanism or induce host polyclonal IgE production which competes with specific IgE (Maizels et al., 2004)

Mast cells express FceRI (high affinity IgE receptor) on their surface and crosslinking of FceRI with IgE/antigen

* Department of Microbiology (Parasitology), Graduate School of Medical Science and Department of Immunology, Medical Institute of Bioregulation, Kyushu University, Fukuoka, Japan.

** Department of Parasitology, Institute of Tropical Medicine, Nagasaki University (NEKKEN), Nagasaki, Japan.

**** Present Address: School of Pharmaceutical Sciences, Nagasaki International University, Sasebo, Japan.

Correspondence: Kanji Watanabe, Department of Parasitology, Institute of Tropical Medicine (NEKKEN), Nagasaki University, 1-12-4 Sakamoto, Nagasaki 852-8523 Japan.

Tel.: +81958197825 - Fax: +81958197805

E-mail: watakanj@nagasaki-u.ac.jp
Résumé : L'EXPULSION DE STRONGYLOIDES RATTI EST INDÉPENDANTE DE LA DÉGRANULATION DES MASTOCYTES VIA LA VOIE DE TRANSDUCTION PAR LE RÉCEPTEUR FCERI

Afin de déterminer si la dégranulation des mastocytes, après agrégation du récepteur de haute affinité des lgE (FcERII, est responsable de l'expulsion des nématodes intestinaux Strongyloides ratti, des souris CD45-/ (déficiente pour l'exon 6 de CD45) sont infectées par le nématode. Chez les souris CD45-/, l'excrétion des œeufs persiste plus de 30 jours après l'inoculation de larves de S. ratti alors que chez les souris de type sauvage $(C D 45+/+)$, il n'y a plus d'excrétion 20 jours post-infection. II y a $75 \%$ en moins de mastocytes au niveau de la muqueuse intestinale chez les souris CD45\%- par rapport aux souris CD45+/+. Le transfert de lymphocytes T de souris sauvage (CD45+/+) aux souris CD45\%- réduit la durée de sécrétion à des niveaux comparables à ceux observés dans le type sauvage avec une augmentation concomitante de mastocytes au niveau de la muqueuse intestinale. Ces résultats montrent que CD45 n'est pas impliquée dans la fonction effectrice des mastocytes de la muqueuse intestinale lors d'une infection par S. ratti. Étant donné que la dégranulation des mastocytes après agrégation du récepteur FcERl est impossible chez les souris CD45\%-, nous en concluons que la dégranulation des mastocytes, dépendante du récepteur FcERl, n'est pas nécessaire pour l'expulsion de S. ratti.

MOTS CLÉS : Strongyloides ratti, expulsion, mastocyte, dégranulation, FCERl.

complexes results in degranulation, which leads to allergic or anaphylactic reaction (Metcalfe et al., 1997). There are also reports which suggest that mast cells have various functions including cytokine secretion, such as IL-4, which is essential for protective Th2 response against bacteria and parasites (Nawa et al., 1994; Frandji et al., 1998; Heib et al., 2008). In wild-type mice infected with Strongyloides, intestinal mast cell levels were increased in accordance with expulsion of the worms (Nawa et al., 1994). In studies performed in mast cell-deficient $\mathrm{W} / \mathrm{W}^{\mathrm{v}}$ mice, the duration of the infection was markedly prolonged (Nawa et al., 1985; Abe et al., 1987). As such, mast cells are critical for expulsion of the intestinal nematodes $S$. ratti and S. venezuelensis (Nawa et al., 1994). Sulfated proteoglycans from mast cells were shown to be involved in the expulsion of the worm from the intestine (Maruyama et al., 2000).

As observed in other helminth infections, Strongyloides infection also induces IgE production. However, it has been suggested that IgE might not be involved in expulsion of Strongyloides from the intestine because IgE levels specific to intestinal worm antigens increased 
after, rather than before, expulsion of adult worm from intestine (Korenaga et al., 1986). In addition, neutralization of IgE does not affect the duration of infection (Korenaga et al., 1991). Furthermore, IL-4 knockout mice, in which IgE was not measurable (Kurup et al., 1999), expelled Strongyloides from the intestine on almost the same day post-inoculation as wild-type mice (Watanabe et al., 2001). On the other hand, there are reports that FcR- $\gamma$ deficient mice which lack IgE/FceR signaling in mast cells could not expel Strongyloides venezuelensis (Onah et al., 2001, Onah \& Nawa, 2004).

CD45 is a transmembrane tyrosine phosphatase expressed on all nucleated hematopoietic cells (Trowbridge et al., 1994). CD 45 activates src family protein tyrosine kinases, essential for antigen receptor-mediated signaling in lymphocytes (Penninger et al., 1993). In CD45 exon6-deficient (CD45-/-) mice, a marked decrease in mature thymocyte levels was observed, suggesting that CD45 is important for thymocyte development and maturation (Kishihara et al., 1993). Moreover, antigen-specific lymphocyte responses were defective in CD45-/mice (Kishihara et al., 1993; Kong et al., 1995). However, analysis of macrophages showed normal antigen presentation and phagocytosis in CD45-/- mice (Berger et al., 1994; Fujise et al., 1997). Interestingly, in CD45-/mice, the FceRI-mediated degranulation of bone marrow derived mast cells (BMMC) was completely impaired and systemic anaphylaxis could not be induced (Berger et al., 1994).

In this study, to address the involvement of FceRI signaling in intestinal mast cell-mediated immunity against $S$. ratti infections, $S$. ratti infection was investigated using CD45 exon-6 knockout mice, which also has a defect in IgE/FceRI-dependent mast cells degranulation (Berger et al., 1994).

\section{MATERIAL AND METHODS}

MicE

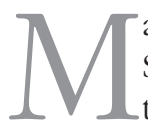
ale C57BL/6 mice were purchased from Japan SLC Inc. (Shizuoka, Japan) and maintained in the Laboratory for the Animal Experiments of Kyushu University under the SPF conditions. CD45 exon6 knockout (CD45-/-) mice were kindly supplied by Dr Tak W. Mak (AMGEN Institute/Ontario Cancer Institute, Toronto, Canada) and maintained in our laboratory. Mice aged 8-12 weeks were used throughout the study. CD45-/- mice have been backcrossed to C57BL/6 mice over seven times. All the experiments were conducted in accordance with the principles and procedures outlined in Guidelines for the Care and Use of Laboratory Animals in Kyushu University.

\section{PREPARATION AND INOCULATION OF PARASITE}

Strongyloides ratti, TMDU strain, has been maintained in our laboratory by serial passage in retired Wistar Rats. Infective larvae (L3) were obtained by filter paper culture of the feces of infected Wistar Rats. Two thousand L3 larvae were suspended in $0.2 \mathrm{ml}$ saline and injected subcutaneously into the lower abdomen of the mouse.

\section{ANALYSIS OF EGG, OUTPUT IN FECES AND LARVAL/ADULT WORMS IN THE TISSUES}

Daily egg output in feces was monitored as follows. Fresh feces $(50-80 \mathrm{mg}$ ) were collected in a $2 \mathrm{ml}$ plastic microtube, weighed and suspended in $1 \mathrm{ml}$ distilled water. The number of eggs in $50 \mu \mathrm{l}$ of fecal suspension was counted under a microscope. The egg output in feces was presented as eggs per gram of feces (EPG). At 0, 24, 48, 72, 120 hours after infection, mice were sacrificed, organs (head, lung and intestine) were removed and cut into pieces. Minced tissues were incubated in Petri dishes containing saline at $37^{\circ} \mathrm{C}$ for three hours. Minced tissues were then removed and the worms remaining in the Petri dishes were counted under dissecting microscope. In the head and lungs, third stage larvae were recovered and counted. In the intestine at 120 hours after infection, fourth stage larvae and mainly young adult worms were recovered and counted.

\section{HisTOPATHOLOGICAL ANALYSIS OF INTESTINAL MAST CELLS}

Intestinal sections (1 cm length) located $10 \mathrm{~cm}$ distal to the pylorus were removed and then immersed in Carnoy's fixative solution for two hours. The paraffinembedded samples were cut into sections of $5 \mu \mathrm{m}$ thickness and then stained with Alcian blue ( $\mathrm{pH} 0.3$ ) and Safranin-O according to Abe et al. (1987). The number of intestinal mast cells was counted in 40-60 villous-crypt units (VCU) in each two sections of each mouse. The densities were estimated as intestinal mast cell number per $10 \mathrm{VCU}$.

\section{ADOPTIVE TRANSFER OF WILD-TYPE T CELLS}

Spleen and mesenteric, popliteal and axial lymph nodes were aseptically removed from naïve C57BL/6 mice. The pooled single cell suspension in RPMI 1640 medium supplemented with $10 \%$ heat-inactivated FCS, $2 \mathrm{mM}$ HEPES, $0.2 \%$ sodium bicarbonate and $50 \mu \mathrm{M} 2$-mercaptoethanol was passed through a nylon wool column to enrich $\mathrm{T}$ cells. The recovered cells $\left(1 \times 10^{7} /\right.$ mouse; $\mathrm{T}$ cell purity: $\left.>90 \%\right)$ were intraperitoneally injected into $\mathrm{CD} 45$-/- mice one day before infection. 


\section{STATISTICAL ANALYSIS}

In this study, the Welch test was used to determine statistical significance between two groups. Kruskal-Wallis and post-hoc tests (Dunn test) were used to make com- parisons between three groups. Calculations were performed by GraphPad Prism version 5.00 for Windows, (GraphPad Software, San Diego, California USA, www. graphpad.com). Numerical data obtained from each experiment were displayed as a formula of mean \pm SEM.
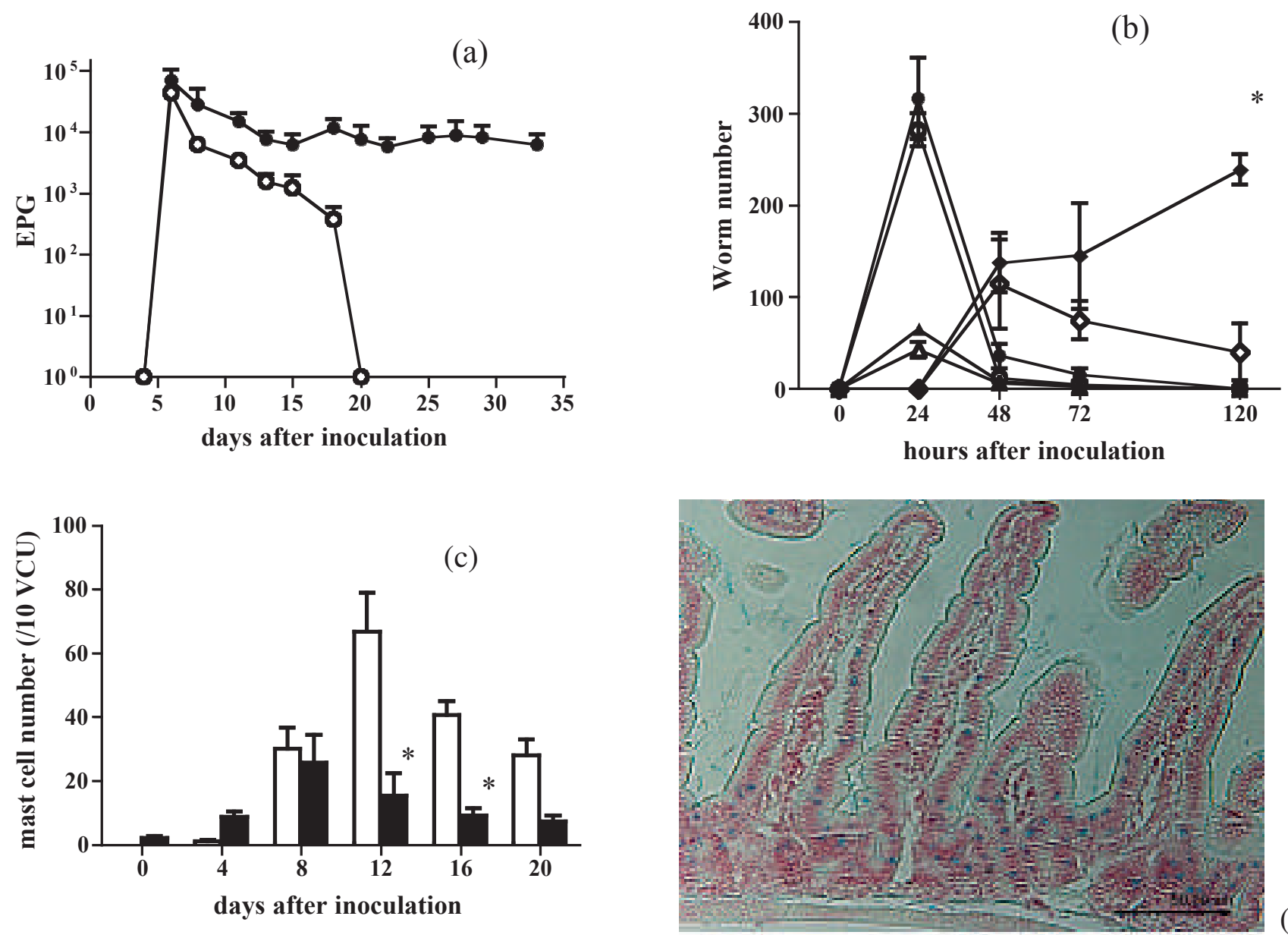

(d)

Fig. 1. - S. ratti infection persisted in CD 45 knockout mice. a. S. ratti infection monitored by egg excretion into feces. CD45 exon-6 knockout mice (CD45-/-) and wild type mice $\left(\mathrm{CD} 45^{+/+}\right)$were inoculated with 2000 S. ratti infective larvae. The number of eggs excreted in feces was monitored and the results are presented as egg number per gram feces. Data represent one of three independent experiments and are shown as mean \pm SEM of four mice in each group. Open symbols, CD $45+/+$, Closed symbols, CD $45-/-$

b. Worm number in head, lung and intestine in each group of mice. Mice were sacrificed at indicated hours and the number of larvae in each organ was counted as described in material and methods. Data are shown as mean \pm SEM of three mice and represent one of two independent experiments. Open symbols: CD45+/+; Closed symbols: CD45-/-. Circles: the number of larvae in the head; Triangles: the number of larvae in the lung; Diamond: the number of larvae in the intestine. ${ }^{*} \mathrm{p}<0.05$ compared with the number in the intestine in $\mathrm{CD} 45+/+$.

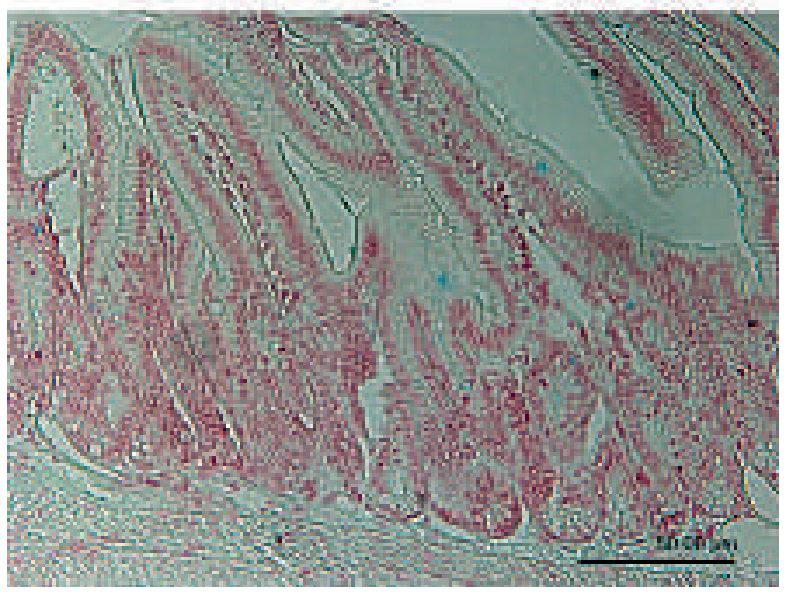

(e)

c. Kinetics of intestinal mast cell numbers during the course of $S$. ratti infection.

Mice were inoculated with $S$. ratti as for figure $2 \mathrm{a}$ and sacrificed on indicated days. Mast cell numbers in the intestine at $10 \mathrm{~cm}$ distal to the pyloric ring were counted. Data are shown as mean \pm SEM of six mice in each group at indicated days. Open bar: CD45+/+; Closed bar: CD $45-/$-. * $\mathrm{p}<0.05$ compared with CD $45+/+$.

d. Section of intestine of CD $45+/+$ mice on day 12, stained with Alcian Blue and Safranin-O. Blue stained spots showed mast cells.

e. Section of intestine of CD45-/- mice on day 12 treated same as d. Few blue stained cells were observed. 


\section{RESULTS}

\section{DECREASED INDUCTION OF INTESTINAL MAST CELLS AND PERSISTENT INFECTION IN CD45-/- MICE DURING $S$. RATTI INFECTION}

T n order to estimate the contribution of IgE/FceRIdependent mast cell degranulation to host defense against S. ratti, CD45-/- mice were inoculated with subcutaneous injection of 2,000 S. ratti L3.

The infection was monitored by the number of eggs excreted into feces (Fig. 1a). The presence of eggs in the feces of CD45-/- mice was detected up to 30 days after inoculation, whereas eggs were not detected from approximately 18-20 days after inoculation in wild type $(\mathrm{CD} 45+/+)$ mice, indicating that the expulsion of this parasite was impaired in CD45-/- mice. Since S. ratti L3 migrate from the inoculated site to the intestine via the head and lung, the number of migrating larvae in the head, lung and intestine were counted at specified hours after inoculation in order to examine whether innate host defense against $S$. ratti migrating larvae was affected in these knockout mice (Fig. 1b). There was no difference in the number of migrating larvae in either the head or lung between the two groups of mice, and a comparable number of worms first appeared in the small intestine 48 hours after infection in both knockout and wild-type mice. The increase of worm numbers was observed in the intestine of CD45-/mice from 72 hours after inoculation.

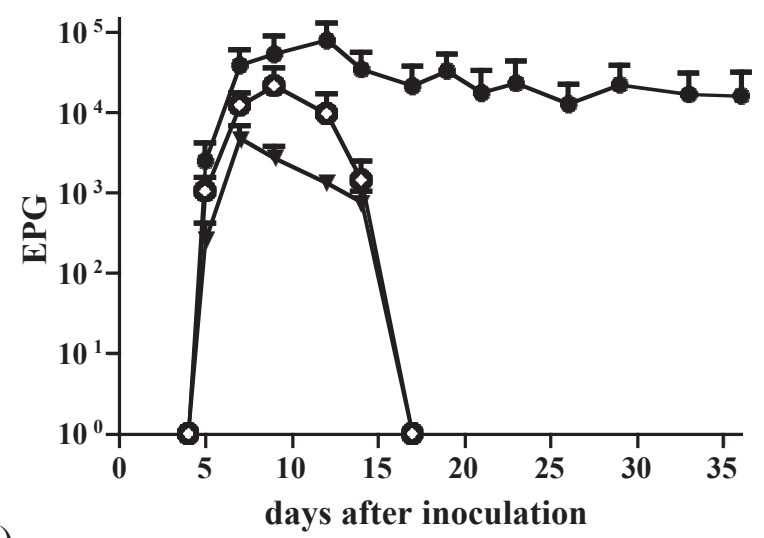

(a)
The number of intestinal mast cells which was shown to be essential for expulsion of Strongyloides, was counted (Fig. 1c, d, e). Before infection, the number of intestinal mast cells observed in CD 45-/- mice was slightly higher than that observed in $\mathrm{CD} 45+/+$ mice (Day 0, CD 45+/+: $0.8 \pm 0.3 / 10 \mathrm{VCU}$; CD45-/-: $2.1 \pm$ $0.6 / 10 \mathrm{VCU})$. The number of intestinal mast cells increased and peaked on day 12 after inoculation in CD $45+/+$ mice, as previously reported, in correlation with $S$. ratti expulsion. The number of mast cells in CD45-/- mice also increased and peaked on days 8-12 after inoculation, with a timing similar to that of $\mathrm{CD} 45+/+$ mice; however, the numbers were $75 \%$ lower than those observed in CD $45+/+$ mice (day 12, CD $45+/+$ : $66.7 \pm$ 12.4/10 VCU; CD45-/-: $15.5 \pm$ 6.8/10 VCU).

\section{ADOPTIVE TRANSFER OF CD45+ WILD-TYPE T CELLS RESTORED EXPULSION OF $S$. RATTI FROM CD 45 KNOCKOUT MICE}

As the antigen-specific $\mathrm{T}$ cell response was completely abrogated in CD45-/- mice (Kishihara et al., 1993; Kong et al., 1995) and the expulsion of nematode from intestine was known to be $\mathrm{T}$ cell-dependent, we transferred $1 \times 10^{7} \mathrm{CD} 45+/+\mathrm{T}$ cells to CD45-/- mice in order to compensate for defective $\mathrm{T}$ cell function. One day after $\mathrm{T}$ cell transfer, mice were inoculated with $S$. ratti. As shown in Figure 2a, the T cell-transferred CD45-/mice expelled S. ratti as effectively as the CD45 +/+ mice. The number of mast cells in the intestine was evaluated in the T cell-transferred CD45-/- mice (Fig. 2b).

Fig. 2 .

a. Adoptive transfer of T cell into CD45 knockout mice curtailed the $S$. ratti infection.

Purified T cells from wild-type mice were intraperitoneally transferred into CD 45 knockout mice. Mice were then inoculated with 2,000 $S$. ratti infective larvae. The number of eggs excreted into feces was monitored and the results are presented as egg number per gram feces. Data are shown for one of two independent experiments. Data are shown as mean \pm SEM in five mice in each group. Open circles: CD 45+/+; Closed circles: CD45-/-; Closed inverted triangle: CD45-/- mice transferred CD 45+/+ T cells.

b. Intestinal mast cells number in T cell-transferred CD45 knockout mice on day 8 and day 12 after inoculation.

Mast cells in the intestine were counted on day 8 and day 12 after larval inoculation. Data are shown as mean \pm SEM of four to seven mice. Data are shown for one of two independent experiments. Open bar: CD $45+/+$; Closed bar: CD $45-/-;$ Shaded bar: T cell-transferred CD 45-/-. p < 0.05 within group by Kruskal Wallis test. * $\mathrm{p}<0.05 \mathrm{~T}$ cell transferred CD45-/- vs CD45+/+ *** $\mathrm{p}<0.05$ CD 45-/- vs CD45+/+ by Dunn test. 
Interestingly, on day 8 , the increase in mast cell numbers was higher in T cell-transferred CD45-/- mice compared with $\mathrm{CD} 45+/+$ and $\mathrm{CD} 45-/-$ mice $(\mathrm{CD} 45+/+$ : $40.4 \pm 9.7$; CD 45-/-: $46.3 \pm$ 8.6; $\mathrm{T}$ cell transferred CD45-/-: $81.8 \pm 13.5 / 10$ VCU). On day 12 , when mast cell numbers peaked in $\mathrm{CD} 45+/+$ mice, those in $\mathrm{T}$ cell transferred CD $45-/-$ mice continued to increase, although to a lesser extent than that observed on day $8(\mathrm{CD} 45+/+$ : $89.6 \pm 4.4 ; \mathrm{CD} 45-/-: 23.0 \pm 5.9$; T cell transferred CD45-/-: $39.2 \pm 12.4$ / 10VCU).

\section{DISCUSSION}

N ematode infection induces stereotypic Th2 responses, such as eosinophilia, mast cell and goblet cell hyperplasia, and elevated serum IgE titer (Maizels et al., 2004), suggesting that these responses may be protective against intestinal nematode infection.

Among the various Th2 responses, it has been shown that mast and goblet cells function as effector cells in the intestine against nematode infection (Nawa et al., 1985; Abe et al., 1987; McKenzie et al., 1998). The significance of each cell varies, depending on the species of nematode. In Strongyloides infection, intestinal mast cells are considered to be more important in enabling the host to expel the parasite, whilst in Nippostrongylus infection, goblet cells are thought to play a more significant role (Nawa et al., 1994). Furthermore, non-bone marrow-derived cells, which included intestinal epithelium, were reported to contribute to the expulsion of Nippostrongylus through increased contractility of intestine and enhanced permeability of epithelium (Urban et al., 2001).

Mast cells express high affinity receptors for IgE (FcERI) and cross-linking of IgE/FceRI induces degranulation which contains many physiologically active molecules (Metcalfe et al., 1997). In this study, we examined the involvement of IgE/FceRI signaling in the mast celldependent expulsion of $S$. ratti using CD45 exon6 knockout mice.

We showed that knockout mice supplemented with wild type T cells could expel $S$. ratti from the intestine. It has been reported that $\mathrm{CD} 45$-deficient mast cells cannot induce IgE-dependent degranulation either in vitro or in vivo (Berger et al., 1994). Taken together, our study suggests that IgE-dependent degranulation is not essential for the protective function of intestinal mast cells against $S$. ratti. Degranulation itself is considered necessary for protection as sulfated proteoglycan, which is contained in mast cell granules, is essential for expulsion of $S$. venezuelensis (Metcalfe et al., 1997; Maruyama et al., 2000). Two reports showed results which conflicted with our study that $S$. vene- zuelensis expulsion was delayed in accordance with decreased release of proteoglycan into intestinal lumen using FcR- $\gamma$ chain knockout mice which also had defect in IgE mediated degranulation of mast cells (Onah et al., 2000, Onah \& Nawa, 2004). So further study is expected to reveal which machinery of mast cell are essential for expulsion of parasite.

Since the antigen-specific $\mathrm{T}$ cell response is completely abrogated in CD45-/- mice (Kishihara et al., 1993; Kong et al., 1995) and protective immunity against the nematode is dependent on CD $4 \mathrm{~T}$ cells (Urban et al., 1995; Fowell et al., 1997), it was anticipated that the transfer of wild-type $\mathrm{T}$ cells would be essential in enabling CD45-/- mice to expel the parasite. In our study, wild-type $\mathrm{T}$ cell transfer led to successful expulsion of the parasite from the host in CD45-/mice with a concomitant increase in intestinal mast cells.

With regard to induction of intestinal mast cells, CD4 $\mathrm{T}$ cells, particularly Th2 cells, are thought to play an important role because they produce cytokines, IL-4, IL-9, and IL-10, all of which are necessary for effective proliferation, maturation and survival of mast cells (Okayama et al., 2006). It can therefore be assumed that, in our study, the transferred $\mathrm{T}$ cells supported the effective proliferation and maturation of intestinal mast cells through cytokine production.

Surprisingly, mast cell numbers in $\mathrm{T}$ cell transferred CD45-/- mice had increased as early as day 8. A study reported that CD45 suppresses JAK kinase and negatively regulates cytokine receptor signaling (Irie-Sasaki et al., 2001). In that report, BMMC from CD 45-/- mice exhibited higher levels of proliferation in response to IL-3 compared with BMMC from CD45+/+ owing to increased JAK-STAT signaling in the absence of CD45. In our experiment, mast cells in $\mathrm{T}$ cell-transferred CD45-/- mice effectively proliferated, presumably in response to the cytokine produced by the transferred $\mathrm{T}$ cells, and increased as early as day 8 .

In summary, we showed that CD45-deficient mice supplemented with $\mathrm{T}$ cell from wild type mice could expel $S$. ratti from the intestine. Because mast cells of CD45 knockout mice fail to induce degranulation in a IgE/FcERI-dependent manner (Berger et al., 1994), our study implicated that IgE/FcERI signaling is not required for mast cell-dependent worm expulsion in Strongyloides ratti primary infection.

\section{ACKNOWLEDGEMENTS}

his work is supported, in part, by the Grant in aid for scientific research from the Japanese Ministry of Education, Science, Sports and Culture, Tokyo, Japan (No 08457081). 


\section{REFERENCES}

ABE T. \& NAWA Y. Reconstitution of mucosal mast cells in $\mathrm{W} / \mathrm{W}$ mice by adoptive transfer of bone marrow-derived cultured mast cells and its effects on the protective capacity to Strongyloides ratti-infection. Parasite Immunology, 1987, 9, 31-38.

Berger S.A., MaK T.W. \& Paige C.J. Leukocyte common antigen (CD45) is required for immunoglobulin E-mediated degranulation of mast cells. Journal of Experimental Medicine, 1994, 180, 471-476.

Fowell D.J., Magram J., Turck C.W., Killeen N. \& Locksley R.M. Impaired Th2 subset development in the absence of CD4. Immunity, 1997, 6, 559-569.

Frandj P., Mourad W., Tkaczyk C., Singer M., David B., Colle J.H. \& MECHERI S. IL-4 mRNA transcription is induced in mouse bone marrow-derived mast cells through an MHC class II-dependent signaling pathway. European Journal of Immunology, 1998, 28, 844-854.

Fujise S., Kishinara K., Lee K.Y., Matsuzaki G. \& Nomoto K. Normal macrophage functions, but impaired induction of gamma delta $\mathrm{T}$ cells, at the site of bacterial infection in CD45 exon 6-deficient mice. European Journal of Immunologl, 1997, 27, 2549-2556.

Heib V., Becker M., Taube C. \& Stassen M. Advances in the understanding of mast cell function, British Journal of Haematology, 2008, 142, 683-694.

Irie-SASAKi J., Sasaki T., Matsumoto W., Opavsky A., Cheng M., Welstead G., Griffiths E., Krawczyk C., Richardson C.D., Aitken K., Iscove N., Koretzky G., Johnson P., Liu P., RothSTEIN D.M. \& PENninger J.M. CD45 is a JAK phosphatase and negatively regulates cytokine receptor signalling. Nature, 2001, 409, 349-354.

Kishihara K., Penninger J., Wallace V.A., Kundig T.M., Kawai K., Wakeham A., Timms E., Pfeffer K., Ohashi P.S., Thomas M.L. et al. Normal B lymphocyte development but impaired $\mathrm{T}$ cell maturation in CD45-exon6 protein tyrosine phosphatase-deficient mice. Cell, 1993, 74, 143-156.

Kong Y.Y., Kishinara K., Yoshida H., MaK T.W. \& Nomoto K. Generation of T cells with differential responses to alloantigens in CD45 exon 6-deficient mice. Journal of Immunology, 1995, 154, 5725-5735.

Korenaga M., Nawa Y. \& Tada I. IgE response in Strongyloides ratti-infected rats with special reference to the life cycle of the parasite. Zeitschrift für Parasitenkunde, 1986, 72, 213-220.

Korenaga M., Watanabe N. \& TADA I. Effects of anti-IgE monoclonal antibody on a primary infection of Strongyloides ratti in mice. Parasitology Reearchs, 1991, 77, 362363.

Kurup V.P., Choi H.Y., Murali P.S., XIa J.Q., Coffman R.L. \& FINK J.N. Immune responses to Aspergillus antigen in IL4-/- mice and the effect of eosinophil ablation. Allergy, 1999, 54, 420-427.

Maizels R.M., Balic A., Gomez-Escobar N., Nair M., Taylor M.D. \& AllEN J.E. Helminth parasites-masters of regulation. Immunological Review, 2004, 201, 89-116.
Maruyama H., Yabu Y., Yoshida A., Nawa Y. \& Ohta N. A role of mast cell glycosaminoglycans for the immunological expulsion of intestinal nematode, Strongyloides venezuelensis. Journal of Immunology, 2000, 164, 3749-3754.

McKenzie G.J., Bancroft A., Grencis R.K. \&. McKenzie A.N. A distinct role for interleukin-13 in Th2-cell-mediated immune responses. Current Biology, 1998, 8, 339-342.

Metcalfe D.D., Baram D. \& MeKori Y. Mast cells. Physiological Review, 1997, 77, 1033-1079.

Nawa Y., Ishikawa N., Tsuchiya K., Horit Y., Abe T., Khan A.I., Bing S., ITOH H., Ide H. \& Uchiyama F. Selective effector mechanisms for the expulsion of intestinal helminths. Parasite Immunology, 1994, 16, 333-338.

Nawa Y., KiYota M., Korenaga M. \& Kotani M. Defective protective capacity of $\mathrm{W} / \mathrm{W}^{\mathrm{v}}$ mice against Strongyloides ratti infection and its reconstitution with bone marrow cells. Parasite Immunology, 1985, 7, 429-438.

Okayama Y. \& Kawakami T. Development, migration, and survival of mast cells. Immunological Research, 2006, 34, 97115 .

Onah D.N., Uchiyama F., Nagakui Y., Ono M., Takai T. \& NAWA Y. Mucosal defense against gastrointestinal nematodes: responses of mucosal mast cells and mouse mast cell protease-1 during primary Strongyloides venezuelensis infection in FcR?-knockout mice. Infection and Immunity, 2000, 68, 4968-4971.

ONAH D.N. \& NAWA Y. Mucosal mast cell-derived chondroitin sulphate levels in and worm expulsion from FCR $\gamma$ knockout mice following oral challenge with Strongyloides venezuelensis. Journal of Veterinary Science, 2004, 5, 221-226.

Penninger J.M., Wallace V.A., Kishihara K. \& MaK T. The role of p56lck and p59fyn tyrosine kinases and CD 45 protein tyrosine phosphatase in T-cell development and clonal selection. Immunological Review, 1993, 135, 183-214.

Trowbridge I.S. \& Thomas M.L. CD45: an emerging role as a protein tyrosine phosphatase required for lymphocyte activation and development. Annual Review of Immunology, 1994, 12, 85-116.

Urban J.F. JR., Maliszewski C.R., Madden K.B., Katona I.M. \& FinKelman F.D. IL-4 treatment can cure established gastrointestinal nematode infections in immunocompetent and immunodeficient mice. Journal of Immunology, 1995, 154, 4675-4684.

Urban J.F. Jr., Noben-Trauth N., Schopf L., Madden K.B. \& FinKelman F.D. Cutting edge: IL-4 receptor expression by non-bone marrow-derived cells is required to expel gastrointestinal nematode parasites. Journal of Immunology, 2001, 167, 6078-6081.

Watanabe K., Hamano S., Yada S., Noda K., Kishihara K., Nomoto K. \& TADA I.. The effect of interleukin-4 on the induction of intestinal mast cells and chronological cytokine profiles during intestinal nematode Strongyloides ratti infection. Parasitology Research, 2001, 87, 149-154.

Reçu le 20 janvier 2009 Accepté le 27 avril 2009 